\title{
Studies on physico-chemical constituents in different cultivars of citrus fruits under Lucknow condition, India
}

\author{
Arun Patel $^{1 *}$, Balveer Singh ${ }^{1}$, R. B. Ram ${ }^{2}$ and N. Thirupathi ${ }^{1}$ \\ ${ }^{1}$ Faculty of Horticulture, Bidhan Chandra Krishi Viswa Vidyalaya, Mohanpur, Nadia -741252 (W.B.) INDIA. \\ ${ }^{2}$ Department of Applied Plant Science (Horticulture), Babasaheb Bhimrao Ambedkar University, Vidya-Vihar, Rae \\ Bareli Road, Lucknow- 226025 (U.P.), INDIA \\ Corresponding author. E-mail: pkarun1987@gmail.com
}

Received: March 17, 2015; Revised received: January 24, 2016; Accepted: April 8, 2016

\begin{abstract}
The physico-chemical studies were conducted on the citrus fruits of sweet orange cv. Mosambi Local-1, 2, 3, 4 and 5 and Sweet Mandarin cv. Chinese Orange, Kinnow, Nagpur Mandarin, Local Mandarin-1 and Local Mandarin- 2. The Sweet Orange cultivar was highest size in Mosambi Local-3 with maximum fruit volume $204 \mathrm{ml}$ and flesh weight $139.66 \mathrm{~g}$ followed by Mosambi Local-4. The juice recovery percent was maximum in Mosambi Local-3 28.63 and the highest specific gravity was found in Mosambi Local-1 (0.99) followed by Mosambi Local-2 (0.94). The different cultivars of Sweet Orange were recorded varies from the total soluble solid 7.60 to 12.66 per cent, reducing sugar 4.13 to 7.08 per cent, total sugar 5.90 to 10.12 per cent, tritrable acidity 0.52 to 0.83 per cent, ascorbic acid 46 to $74.80 \mathrm{mg} / 100 \mathrm{~g}$ and $\mathrm{pH} 3.92$ to 4.98 . The juice percent was determined in Kinnow $53.20 \mathrm{~g}$ after that Nagpur santra $51.30 \mathrm{~g}$. The chemical attributes of Sweet Mandarin were found as total soluble solid varied from 8.96 to 12.20 per cent, reducing sugar 3.22 to 6.60 per cent, total sugar 5.73 to 10.04 per cent, titrable acidity 0.84 to 2.24 per cent, ascorbic acid 25.96 to $36.13 \mathrm{mg} / 100 \mathrm{~g}$ and $\mathrm{pH} 3.84$ to 4.60 . However, the Sweet Orange cultivars Mosambi Local-3 and Mosambi Local-4 and Sweet Mandarin cv. Local Mandarin-1 were suitable for export, making of non alcoholic beverages, easy for bottling and frozen products grown under Lucknow conditions.
\end{abstract}

Keywords: Acidity, Citrus fruit, Nutritive value, Sugar

\section{INTRODUCTION}

The Citrus crop belongs to family Rutaceae. It claims to be the second most important commercial fruit in India area after mango. It is believed that most of the species under the genus citrus are native to tropical and subtropical region of Southeast Asia, particularly India and China. The north eastern region of India is considered as one of the natural home of citrus. Citrus fruit is type is hespiridium, globose or oblong, small to large in size, yellow to orange coloured, rind with varying thickness, dotted with oil glands, pulp consists of juice vesicles, acidic to sweet, seeds are few to many either monoembryonic or polyembryonic. The rind of citrus fruit is rich in pectin and certain essential oils. Citrus fruit content considerable amount of ascorbic acid (Lgwe, 2014). The total soluble solid are most of the sweet group of citrus, varies from $8-12^{0}$ Brix, while the titrable acidity usually ranges from 0.5 to 1.5 percent Ghosh et al. (1985). The two species juice percentage was found higher in mandarin then sweet orange (Khan et al., 2010). Besides worldwide demand of orange as fresh fruit, Sweet Orange and Mandarin juices are bottled; canned and large scale beverages are prepared from the common citrus fruit. The production of canned juice and pulp and particularly of frozen concentrated juice has been increasing very rapidly throughout the world. So the present study was undertaken to study the physico-chemical constituents in different cultivars of citrus fruits grown under Lucknow condition.

\section{MATERIALS AND METHODS}

The experiment was conducted at the Horticultural Research Farm, Babasaheb Bhimrao Ambedkar University, Lucknow during 2011 with different cultivars of sweet orange and sweet mandarin. Ten mature fruits from each plant collected randomly, were completely randomized block design with four replications analysed for physico-chemical characteristics. Ten fully matured fruits size and thickness of peel was recorded with the help of Vernier Callipers. The fruit flesh and peel weight of 10 fruit in each cultivar in each replication was estimated with the help of an electronic balance. The colour of citrus fruits were evaluated by the evaluation was based mainly on the visual basis (Phenotipically). The volume of fruits was determined by water displacement method. The weight of fruit was divided by volume of displaced water for specific gravity. The flesh: peel ratio was calculated by weight of flesh divided by weight of peel. Juice percentage was calculated by weight of fruit juice divided by 
weight of fruit. The number of seed counted after extracted of seed from fruits. The total soluble solids were determined by using a hand refractometer by Ranganna (1991). The $\mathrm{pH}$ of the samples was measured with a digital $\mathrm{pH}$ meter (Model HC-200). The total titratable acidity was determined by volumetric procedure. The known volume of filtered juice after necessary dilution was titrated against standard alkali solution $(\mathrm{N} / 10 \mathrm{NaOH})$ using phenolphthalein indicator and expressed as percentage acidity in terms of citric acid (AOAC, 2000). Ascorbic acid content of the fruit was estimated by using 2, 6 dichlorophenolindophenol dye titration method (Ranganna, 2003). Sugars were estimated by Fehling 'A' and 'B' Solution method given by Lane and Eynon (1943). Total sugar was estimated by adding reducing sugar and non reducing sugar.

\section{RESULTS AND DISCUSSION}

Sweet Orange (C. sinensis): Fruit diameter and per fruit weight are of commercial importance for citrus fruits marketing and trade/business. It is generally considered that in citrus with excessive increase in size the quality is impaired, while on the other side small sized fruits are of low quality (Nawaz et al., 2008). The maximum fruit length was observed in Mosambi Local -3 cultivar and minimum was recorded in Mosambi Local-1 $(5.40 \mathrm{~cm})$. The maximum fruit width was observed in cultivar Mosambi Local-3 $(7.20 \mathrm{~cm})$, while the minimum width of fruit cultivars Mosambi Local-1 $(5.78 \mathrm{~cm})$. The maximum fruit weight was observed in Mosambi Local -4 (163 g) cultivar and minimum was recorded in Mosambi Local-1 (83.66 g). The maximum volume of fruits were recorded in the cultivar Mosambi Local -3 $(204 \mathrm{ml})$ while the cultivar Mosambi Local -1 $(84.00 \mathrm{ml})$ had minimum volume of fruit of Sweet Orange. The maximum specific gravity of fruit was recorded in cultivar Mosambi Local -1 (0.99) while, the minimum specific gravity cultivar Mosambi Local -4 (0.86). The maximum weight of peel was observed in cultivar Mosambi Local -5 (43.33 $\mathrm{g}$ ), while minimum weight of peel in Mosambi Local $2(24 \mathrm{~g})$. The maximum weight of flesh was observed in Mosambi Local -3 (139.66 g) while the cultivar Mosambi Local -1 (55 g) had minimum weight of flesh. The maximum flesh: peel ratio was observed in cultivar Mosambi Local -2 (4.44) and minimum in Mosambi Local -1(1.96). The maximum thickness of peel was observed in cultivar Mosambi Local $-3(0.52 \mathrm{~cm})$ while the minimum thickness of peel in cultivar Mosambi Local-2 $(0.37 \mathrm{~cm})$. The maximum number of Seeds was observed in cultivar Mosambi Local -2 (24) while the cultivar Mosambi Local -4 (6). The maximum $\mathrm{pH}$ was recorded in cultivar Mosambi Local-1 (4.98) and minimum in cultivar Mosambi Local-5 (3.92). The maximum juice percentage was found in cultivar Mosambi Local $-3(39.46 \%)$ while the minimum in cultivar Mosambi Local-1(36.72\%). It is lucid from the table that the cultivar Mosambi Local-1 (yellow), and Mosambi Local-2, Mosambi Local-3, Mosambi Local-4 and Mosambi Local-5 are green/ yellowish in colour. Juice percentage in the citrus fruit is considered to be very important. The ultimate demand of customer is higher juice percentage in the fruit. Results regarding the juice percentage revealed significant differences among different cultivars. Hashmi et al. (2012) found that the physical characteristics of sweet orange skin colour (greenish yellow), average weight $(199 \mathrm{~g})$, average diameter $(84.06 \mathrm{~mm})$, thickness $(2.34 \mathrm{~mm})$, weigth of peel $(47.1 \mathrm{~g})$, weight of seed (12.6 g), number of seed (17) and juice percent (37.95). The maximum Total soluble solid was recorded in cultivar Mosambi Local-1 (12.66 ${ }^{\circ}$ Brix $)$ and minimum in cultivar Mosambi Local-5 (7.6 ${ }^{0}$ Brix). Lowest acidity was recorded in cultivar Mosambi Local-2 $(0.52 \%)$ and highest in cultivar Mosambi Local-5 $(0.83 \%)$. The maximum ascorbic acid was recorded in cultivar Mosambi Local-4 (66.24 mg/100g) and minimum in cultivar Mosambi Local-2 $(42.91 \mathrm{mg} / 100 \mathrm{~g})$. The highest reducing and total sugar per cent was found in Mosambi Local-1 (7.08), (10.12) and minimum in cultivar Mosambi Local-5 (4.13) and (5.90) respectively.

Sweet Mandarin ( $C$. reticulate): The cultivar Local Mandarin -1 had maximum fruit length $(6.5 \mathrm{~cm})$ while the cultivar Kinnow $(5.12 \mathrm{~cm}$ ) had minimum fruit length. The cultivar Chinese Mandarin $(6.74 \mathrm{~cm})$ had maximum breadth of fruits, while the cultivar Nagpur Mandarin $(5.5 \mathrm{~cm})$ had minimum breadth of fruits. The highest fruit weight was found in cv. Local Mandarin $1(124.7 \mathrm{~g})$ and lowest in Kinnow (89 g). The maximum volume of fruits were recorded in the cultivar Local Mandarin -1 (148.2 ml) while the cultivar Kinnow $(92.3 \mathrm{ml})$. The highest specific gravity of fruit was recorded in cultivar Kinnow (0.96) while lowest specific gravity cultivar Local Mandarin -1 (0.83). The maximum peel weight was found in cv. Local Mandarin -1 (29 g) while minimum in cv. Kinnow (13 g). The highest flesh weight was recorded in cv. Local Mandarin -1 (96.1 g) while lowest in Chinese Orange (70 g). The maximum flesh: peel ratio was observed in cultivar Kinnow (5.71) while cultivar Local Mandarin -1 (3.31). The Nagpur Mandarin had maximum thickness of peel $(0.33 \mathrm{~cm})$ while the cultivar Kinnow $(0.16 \mathrm{~cm})$ had minimum thickness of peel. Fruit diameter and per fruit weight are of commercial importance for citrus fruits marketing and trade/business. It is generally considered that in citrus with excessive increase in size the quality is impaired, while on the other side small sized fruits are of low quality (Nawaz et al., 2008). The maximum $\mathrm{pH}$ was found in cultivar Local Mandarin -1 (4.61) and minimum in cultivar Local Mandarin -2 (3.84). The cultivar Kinnow (24) had maximum number of seeds, while the cultivar Chinese orange (13) had minimum number of seeds. In addition to this, Kinnow has very high number of seeds per fruit (20-30 
Table 1. Physical attributes of sweet orange (C. sinensis).

\begin{tabular}{|c|c|c|c|c|c|c|c|c|c|c|c|c|}
\hline $\begin{array}{l}\text { Treat- } \\
\text { ment }\end{array}$ & $\begin{array}{c}\text { Fruit } \\
\text { Leng } \\
\text { th } \\
(\mathrm{cm})\end{array}$ & $\begin{array}{c}\text { Fruit } \\
\text { s } \\
\text { widt } \\
\text { h } \\
\text { (cm) }\end{array}$ & $\begin{array}{c}\text { Fruit } \\
\text { weight } \\
\text { (g) }\end{array}$ & $\begin{array}{c}\text { Fruit } \\
\text { volume } \\
\text { (ml) }\end{array}$ & $\begin{array}{l}\text { Spe- } \\
\text { cific } \\
\text { grav- } \\
\text { ity }\end{array}$ & $\begin{array}{c}\text { Peel } \\
\text { weight } \\
\text { (g) }\end{array}$ & $\begin{array}{c}\text { Flesh } \\
\text { weight } \\
\text { (g) }\end{array}$ & $\begin{array}{l}\text { Flesh } \\
\text { peel } \\
\text { ratio }\end{array}$ & $\begin{array}{c}\text { Thick- } \\
\text { ness of } \\
\text { peel } \\
(\mathrm{cm})\end{array}$ & $\begin{array}{l}\text { No. of } \\
\text { seed } \\
\text { per } \\
\text { fruit }\end{array}$ & $\begin{array}{c}\text { Juice } \\
(\%)\end{array}$ & $\begin{array}{l}\text { Skin } \\
\text { colour }\end{array}$ \\
\hline $\begin{array}{l}\text { Mosambi } \\
\text { Local-1 }\end{array}$ & 5.40 & 5.78 & 83.67 & 84 & 0.99 & 28 & 55 & 1.96 & 0.45 & 8 & 36.72 & Yellow \\
\hline $\begin{array}{l}\text { Mosambi } \\
\text { Local-2 }\end{array}$ & 6.23 & 6.43 & 136.66 & 139 & 0.94 & 24 & 106.66 & 4.00 & 0.37 & 24 & 37.59 & $\begin{array}{l}\text { Green } \\
\text { yellowish }\end{array}$ \\
\hline $\begin{array}{l}\text { Mosambi } \\
\text { Local-3 }\end{array}$ & 7.36 & 7.20 & 150.00 & 204 & 0.89 & 40.33 & 139.66 & 3.46 & 0.52 & 8 & 39.46 & $\begin{array}{l}\text { Green } \\
\text { yellowish }\end{array}$ \\
\hline $\begin{array}{l}\text { Mosambi } \\
\text { Local-4 }\end{array}$ & 6.66 & 7.04 & 163.00 & 188 & 0.86 & 40.66 & 122.66 & 3.01 & 0.45 & 6 & 28.63 & Yellow \\
\hline $\begin{array}{l}\text { Mosambi } \\
\text { Local-5 }\end{array}$ & 6.43 & 6.79 & 152.00 & 164.40 & 0.92 & 43.33 & 109.00 & 3.51 & 0.51 & 18 & 37.69 & $\begin{array}{l}\text { Light yel- } \\
\text { low }\end{array}$ \\
\hline $\begin{array}{c}\text { CD. at } \\
5 \%\end{array}$ & 0.87 & 0.87 & 18.43 & 20.96 & 0.06 & 4.94 & 14.01 & 0.37 & 0.06 & 1.67 & 2.56 & \\
\hline
\end{tabular}

Table 2. Chemical attributes of sweet orange (C. sinensis).

\begin{tabular}{|c|c|c|c|c|c|c|c|}
\hline Treatment & $\begin{array}{c}\text { TSS } \\
{ }^{\mathbf{b}} \text { brix }\end{array}$ & $\begin{array}{c}\text { Titrable } \\
\text { acidity } \\
(\%)\end{array}$ & $\begin{array}{l}\text { Ascorbic acid } \\
(\mathrm{mg} / \mathbf{1 0 0 g})\end{array}$ & $\begin{array}{l}\text { Reducing } \\
\text { sugar }(\%)\end{array}$ & $\begin{array}{c}\text { Non-reducing sugar } \\
(\%)\end{array}$ & $\begin{array}{c}\text { Total sugar } \\
(\%)\end{array}$ & $\mathrm{pH}$ \\
\hline Mosambi local-1 & 12.66 & 0.53 & 58.81 & 7.08 & 3.04 & 10.12 & 4.98 \\
\hline Mosambi local-2 & 8.26 & 0.52 & 42.91 & 4.65 & 1.75 & 6.4 & 4.43 \\
\hline Mosambi local-3 & 8.33 & 0.55 & 74.8 & 4.83 & 1.41 & 6.24 & 4.65 \\
\hline Mosambi local-4 & 9.7 & 0.64 & 66.24 & 5.24 & 1.74 & 6.98 & 4.96 \\
\hline Mosambi local-5 & 7.6 & 0.83 & 46.00 & 4.13 & 1.77 & 5.90 & 3.92 \\
\hline CD. at $5 \%$ & 1.17 & 0.09 & 7.71 & 0.18 & 0.057 & 0.24 & 0.37 \\
\hline
\end{tabular}

Table 3. Physical attributes of sweet mandarin (C. reticulate).

\begin{tabular}{|c|c|c|c|c|c|c|c|c|c|c|c|c|}
\hline $\begin{array}{l}\text { Treat- } \\
\text { ment }\end{array}$ & $\begin{array}{c}\text { Fruit } \\
\text { Length } \\
\text { (cm) }\end{array}$ & $\begin{array}{c}\text { Fruits } \\
\text { Breath } \\
\text { (cm) }\end{array}$ & $\begin{array}{c}\text { Fruit } \\
\text { weight } \\
\text { (g) }\end{array}$ & $\begin{array}{c}\text { Fruit } \\
\text { volume } \\
\text { (ml) }\end{array}$ & $\begin{array}{l}\text { Specific } \\
\text { gravity }\end{array}$ & $\begin{array}{r}\text { Peel } \\
\text { weig } \\
\text { ht (g) }\end{array}$ & $\begin{array}{c}\text { Flesh } \\
\text { weight } \\
\text { (g) }\end{array}$ & $\begin{array}{c}\text { Flesh } \\
\text { peel } \\
\text { ratio }\end{array}$ & $\begin{array}{l}\text { Thick- } \\
\text { ness of } \\
\text { peel } \\
(\mathrm{cm})\end{array}$ & $\begin{array}{c}\text { No. of } \\
\text { seed } \\
\text { per } \\
\text { fruit }\end{array}$ & $\begin{array}{c}\text { Juice } \\
(\%)\end{array}$ & $\begin{array}{c}\text { Skin } \\
\text { colour }\end{array}$ \\
\hline $\begin{array}{l}\text { Chinese } \\
\text { Orange }\end{array}$ & 5.67 & 6.74 & 93.00 & 102 & 0.96 & 20 & 70 & 3.50 & 0.21 & 13 & 48.96 & $\begin{array}{c}\text { Dark } \\
\text { orange }\end{array}$ \\
\hline Kinnow & 5.12 & 5.75 & 89.00 & 92.30 & 0.97 & 13 & 74.33 & 5.71 & 0.16 & 24 & 53.29 & $\begin{array}{c}\text { Dark } \\
\text { orange }\end{array}$ \\
\hline $\begin{array}{l}\text { Nagpur } \\
\text { Santra }\end{array}$ & 6.20 & 5.50 & 110.54 & 124.40 & 0.88 & 24 & 86.80 & 3.61 & 0.33 & 18 & 51.30 & Orange \\
\hline $\begin{array}{l}\text { Local } \\
\text { Manda- } \\
\text { rin-1 }\end{array}$ & 7.50 & 5.60 & 124.70 & 148.20 & 0.84 & 29 & 96.10 & 3.31 & 0.30 & 14 & 49.20 & Orange \\
\hline $\begin{array}{l}\text { Local } \\
\text { Manda- } \\
\text { rin-2 }\end{array}$ & 5.40 & 5.80 & 115.90 & 131.30 & 0.89 & 25 & 90.60 & 3.62 & 0.34 & 15 & 45.40 & $\begin{array}{c}\text { Light } \\
\text { orange }\end{array}$ \\
\hline $\begin{array}{l}\text { CD. at } \\
5 \%\end{array}$ & 0.77 & 0.70 & 13.60 & 16.81 & 0.06 & 3.19 & 11.29 & 0.48 & 0.04 & 2.18 & 3.25 & \\
\hline
\end{tabular}

Table 4. Chemical attributes of sweet mandarin (C. reticulate).

\begin{tabular}{|c|c|c|c|c|c|c|c|}
\hline Treatment & $\begin{array}{c}\text { TSS } \\
{ }^{\mathbf{0} b r i x}\end{array}$ & $\begin{array}{c}\text { Titrable } \\
\text { acidity } \\
(\%)\end{array}$ & $\begin{array}{l}\text { Ascorbic acid } \\
(\mathbf{m g} / \mathbf{1 0 0 g})\end{array}$ & $\begin{array}{l}\text { Reducing } \\
\text { sugar }(\%)\end{array}$ & $\begin{array}{c}\text { Non-reducing suar } \\
(\%)\end{array}$ & $\begin{array}{c}\text { Total sugar } \\
(\%)\end{array}$ & $\mathbf{p H}$ \\
\hline Chinese Orange & 9.66 & 0.84 & 25.96 & 3.22 & 2.51 & 5.73 & 4.05 \\
\hline Kinnow & 10.60 & 1.74 & 33.60 & 6.66 & 3.38 & 10.04 & 3.98 \\
\hline Nagpur Santra & 12.20 & 1.63 & 30.20 & 6.30 & 3.26 & 9.95 & 4.24 \\
\hline Local Mandarin-1 & 11.40 & 2.24 & 34.30 & 6.10 & 2.04 & 8.14 & 4.60 \\
\hline Local Mandarin-2 & 8.96 & 1.07 & 36.13 & 5.80 & 1.60 & 7.43 & 3.84 \\
\hline CD. at $5 \%$ & 1.36 & 0.22 & 3.89 & 0.78 & 0.31 & 1.13 & 0.28 \\
\hline
\end{tabular}

seeds/fruit) and cannot be used in the processing industry for juice extraction (Anwar and Ibrahim, 2004). The maximum juice per cent was observed in cultivar Kinnow (53.29) and minimum in Local Mandarin -2 (45.4). The colour Chinese orange and Kinnow were found dark orange and Nagpur Mandarin, Local Mandarin -1 and Local Mandarin -2 are orange colour. The maximum total soluble solid was recorded in cultivar Nagpur Mandarin (12.2 ${ }^{0}$ Brix $)$ and minimum in cultivar Local Mandarin-1 (8.96 ${ }^{0}$ Brix $)$. The minimum acidity was found in cultivar Chinese Orange (0.84\%) and maximum in cultivar Local Mandarin-1 (2.24\%). The maximum ascorbic acid was observed in cultivar Local Mandarin-1 (34.30 mg/100g) and minimum in 
cultivar Chinese Orange $(25.96 \mathrm{mg} / 100 \mathrm{~g})$. The temperature increased, ascorbic acid content decreased. However, one of the major sugars found in juices, fructose, can also cause ascorbic acid breakdown. Conversely, higher levels of citric and malic acids stabilize ascorbic acid (Atinmo et al., 1981). The highest reducing sugar was recorded in cultivar Kinnow (6.66\%) and minimum in cultivar Chinese Orange (3.22\%). The maximum reducing sugar was recorded in cultivar Nagpur Mandarin (3.38\%) and minimum in Local Mandarin-1 (1.6\%). The highest total sugar was recorded in cultivar Kinnow (10.04\%) and minimum in Chinese Orange (5.73\%).

\section{Conclusion}

Among the five cultivars of sweet orange studied Mosambi Local-3 and Mosambi Local-4 cultivars showed the highest content of fruit length, fruit width, flesh weight, juice percent and ascorbic acid. In sweet mandarin cv. Local Mandarin-1 showed the maximum content of fruit length, fruit width, flesh weight, $\mathrm{pH}$, TSS and ascorbic acid. These cultivars of sweet orange and sweet mandarin are suitable for fresh consumption and can be used for the preparation of alcoholic and non alcoholic beverages for industrial purpose.

\section{ACKNOWLEDGEMENTS}

The authors are grateful to Dr. Sanjay Kumar, Head, Department of Applied Plant Science (Horticulture), Baba Saheb Bhimrao Ambedker Central University, Vidhya Vihar, Raibareli Road, Lucknow, for providing necessary facility and guidance to complete this study.

\section{REFERENCES}

Anwar, R. and Ibrahim, M. (2004). Is Kinnow better that orange? University of Agriculture, Faisalabad, Pakistan. Proc. the $1^{\text {st }}$ Int. Conf. Citriculture, pp: 196-199.

AOAC (2000). Offcial methods of analysis, association of official agricultural chemists, Washington, D.C.

Atinmo, T. Ogunta, T. Okorie, A.U. and Kamalu, T.M. (1981). Nutrition and good health. Nigerian J. of Nutritional Sci., 2(2): 80-85.

Ghosh, D. Mitra, S.K. and Bose, T.K. (1985). Effect of magnesium, zinc, copper, boron, manganese and iron on growth, yield and fruit quality of mandarin orange. Proc. Third Nat. Citrus Sym., p. 12.

Hashmi, S.H. Ghatge, G. Machewad, G.M. and Pawar, S. (2012). Studies on Extraction of essential oil and pectin from sweet orange. Open Access Scientific Reports. 1 (3/4): 291.

Khan, I.Z.A. Shah, M. Saeed, H.U.S. (2010). Physicochemical analysis of Citrus sinensis, Citrus reticulate and Citrus paradise in Taranab, Peshawar Pakistan. J. chem. Soc. Pak., 32(6):774-780.

Lane, J.H. and Eynon, L. (1943). Determination of reducing sugar by means of Fehlings solution with methylene blue as an internal indicator. J. Soc. Chem. India. 42: 327.

Lgwe, O.U. (2014). Quantitative estimation of ascorbic acid levels in citrus fruits at variable temperatures and physicochemical properties. International J. of Chem. and Biochemical Sci., 5: 67-71.

Nawaz, M.A. Ahmad, W. Ahmad, S. and Khan. M.M. (2008). Role of growth regulators on preharvest fruit drop, yield and quality in Kinnow mandarin. Pak. J. Bot., 40: 1971-1981.

Ranganna, S. (1991). Hand book of analysis and quality control for fruit and vegetables products third edition, Tata McGraw Hill Pub, Co. Ltd. New Delhi, India.

Ranganna, S. (2003). Hand book of analysis and quality control for fruits and vegetable products. Tata McGraw -Hill Pub Company Limited New Delhi 11-12. 